\title{
Evaluating co-operative schools: values, democracy and leadership
}

Tom Woodin

Co-operative schools represent an attempt to democratise and co-operativise English education. They provide an alternative perspective which looks both back to progressive traditions as well as forward to a democratic and inclusive education system in which pupils, parents and communities are active partners in schools and their networks. Co-operativism and inclusion make interesting collaborators although the connections also throw up challenges and contradictions, many of which are explored in this special issue on cooperative schools: values, democracy and leadership.

Co-operative ethos and governance have been twin pillars of the movement. The legal models for such schools specify the promotion and support of co-operative values and principles which include democracy, solidarity, equity, equality, self-help and selfresponsibility (DfE 2016). In addition, co-operative schools are expected to develop multistakeholder governance in which staff, pupils, parents, communities and, potentially, alumni play a role through a 'forum' which represents their views. From these legal outlines, schools have shaped a great diversity of co-operative structures and administrative arrangements. Many contemporary schools are hierarchical structures in which individual schools and teachers toe the line in terms of curriculum, pedagogy, finance and other factors. By contrast, co-operative schools come together as equal partners to define their futures. It has made for a variegated labyrinth of co-operative schools defined by partners working collaboratively for common benefit. Certain schools have focused on, for example, curriculum and pedagogy or developing membership schemes and pupil participation. However, it must be noted that co-operative schools are not true co-operatives. They cannot fully apply co-operative principles, which really tie down the values to a specific set of practices. For instance, they are not fully 'autonomous' bodies and 'member economic participation' does not translate directly into the working of a school (ICA 2019). Rather they should be seen as 'hybrid' structures which amalgamate elements of co-operative practice 
and values into the English education system (Woodin 2015: 6). It is the ambiguous and flexible nature of co-operative schools which helps to explain their significance and connects this novel initiative to a common history.

The co-operative movement has a long interest in education which means that schools fit comfortably within its family. A long-standing principle specifically refers to 'education, training and information'. Historically in Britain, the movement played an important role in the development of state education, incubating new ideas and developing educational models that would later be adopted on a widespread basis (Gurney 1996; Woodin 2011; Todd 2013; Vernon 2013). This trend stretched from the early nineteenth well into the twentieth century. The movement also developed its own educational provision across the age range, from an early age up to adulthood. It established institutions such as the Co-operative College in 1919 which is still in existence and has played a crucial initiating and brokering role in the development of co-operative schools (Woodin, Vernon and Shaw 2019 forthcoming).

The contemporary incarnation of co-operative schooling developed from the early 2000 s when the Co-operative Group, Britain's largest consumer co-operative, sponsored ten business and enterprise colleges under the 'specialist schools' scheme, at a cost of approximately £1 million. The Co-operative College had already been looking for opportunities to create a network of schools interested in co-operation. The coming together of these partners contributed to a momentum for change. With the demise of specialist schools, as policy priorities shifted, alternatives were actively sought out, partly in response to demand from schools themselves. An opportunity arose with the passing of the 2006 Education and Inspections Act which paved the way for groups of schools to form trusts, bring in a range of partners onto governing bodies, and take ownership of land, while remaining part of the local authority. Co-operative values were fed into a democratic governance structure. Subsequently, as the Coalition Government of 2010-2015 encouraged all high performing schools to become academies, co-operative academy models were also worked out. Academy schools have been referred to as 'independent state schools' and 
enjoy some freedom over recruitment, pupil selection and curriculum and are also managed through a contract with the DfE.

The relative success of co-operative schools illustrates how education policy, while reflecting a clear direction of travel (Chitty 2014), has not entirely killed off community-based education. Central government has appealed to parents as consumers who exercise choice with the benefit of simplified league tables but this is open to challenge. These relationships are unstable, partly because stakeholders are expected to support the educational project which they are not liable to do on the basis of a business transaction. Politicians have been aware that co-operative schools address the policy conundrum whereby control of schools has been ceded to small cliques yet requires the support of parents and communities (House of Commons 2013). The encouragement of critical learners may also lead to dialogue and self-exploration which might confound a close match between pedagogy and learning.

Co-operative schooling cuts across educational, economic and social boundaries and has provoked contrasting and confused reactions. Sympathisers emphasise that it is an alternative based upon inclusion and participation, working from within and against the restrictions of neoliberalism. Other fellow travellers have lent partial support to the system because it promises to deliver part of their vision, whether that be for a more locally based education system, for more democracy and pupil participation in schools or for mutual structures which help to deliver economies of scale and greater efficiency (Woodin and Fielding 2013). A level of political support has been visible not only from those associated with co-operative traditions but also, for instance, by right wing politicians attracted by the voluntary nature of the movement and the focus upon self-help and self-responsibility (Ralls 2019 in press). Indeed, some proponents of co-operative schools found that they had to pinch themselves when meeting with Conservative ministers who complained that the Labour administrations of Tony Blair and Gordon Brown had been too soft on the private sector and that community models needed to be more robust (CEO 2016). Conversely, 
among the critics, both policy makers and defenders of local education authorities have dismissed co-operative schools as either hopelessly utopian or as a surreptitious form of privatisation. Silence and incomprehension has been a further response, perhaps in the hope that such oddball schools will go away. Some policy makers have lent surface support but worked behind the scenes to marginalise co-operative schools.

Despite its potential to proliferate rapidly, and its promise to be the kernel of a new education system, the co-operative experiment may prove to be short lived, a common experience for radical and alternative impulses. From the formation of the first trust school in 2008, the number of co-operative schools multiplied rapidly to 850 by 2013 but this number then declined to less than 600 by 2016 and current estimates vary between 330 and 500 (for instance see Co-operativesUK 2018). Some of the reasons for this are partly explored in this issue. The attempt to bring about change faces several inconsistencies which cannot be overcome in a simplistic manner. For instance, building a sustainable apex body which effectively supports and represents co-operative schools is a crucial challenge confronting the movement. For some schools, co-operative status was a marriage of convenience that could easily be discarded when a better offer came along. For others, keen to avoid forced academisation into a chain of schools, the co-operative offer afforded short term relief. Indeed, co-operative schools that were found to be 'failing' or 'coasting' would be pressed into non-co-operative alliances at the behest of the Department for Education. At the same time, all reform movements face the challenge of the continuing 'grammar of schooling' which inevitably tempers radical policy changes (Tyack and Cuban 1995). Thus, evaluating the co-operative movement's role in wider educational arenas becomes urgent, and inclusion is a crucial aspect of this.

Co-operative schools are not a silver bullet for inclusion, they do not solve complex dilemmas and engrained inequalities cannot simply be overcome with the application of new names and structures. But they do potentially facilitate debate and popular deliberation. Cooperative values emphasise equality and equity, standing together with others in solidarity as 
well as nurturing the agency of individuals and groups through self-help and selfresponsibility. Consequently, they have carved out a space in which inclusive education can be revisited. In assessing the relevance of co-operation for inclusive education, we must be alert to the complex interconnections between philosophical positions and administrative arrangements. Len Barton emphasises that inclusive education is a means to an end which is an inclusive society (for instance, Barton 1988). This sets the bar very high for inclusive education in the same way that some commentators do for co-operative education (see Davidge, Facer and Schostak 2015; Shostak in this issue).

In working towards an inclusive society, inclusive education has been taken on by policy makers, which has considerably broadened its definition. The meaning of inclusion has thus extended from a set of specific radical practices by social movements to a generic and widely adopted idea, part of everyday educational discourse. Furthermore, the internationalisation of inclusive education has been linked to the Education for All movement and the World Forums, starting with Jomtiem in 1990 and particularly Salamanca in 1994 (UNESCO 1994). Through the process of global proliferation, the term has been attached to a myriad of often conflicting perspectives. In different countries, it may refer to the extension of compulsory schooling or overcoming debilitating historical trends relating to disability, gender, race and sexuality. It has even come to include separating out children with special needs via the provision of bespoke services, in opposition to the initial impulse behind inclusion.

Supporters of inclusive education hanker after the purity and force of the originating theoretical insights and the urge for general transformation but are troubled by the actual process of change which entails a subtle neutering of their radical visions as ideas are adopted and transformed by the mainstream. The language of inclusive education has become a lingua franca, removed from its originating constituency from which it drew its force. Roger Slee (2018: 10) opines the waning of its early radical content 
The near perfect attempt to silence inclusive education through the colonisation of its language' which 'diminishes inclusive education's original manifesto of justice for children and young people with disabilities. (Ibid., 11)

Education policy has thus embraced the language of inclusion but squeezed it into new shapes (Barton and Armstrong 2007). Whereas in the past many students, who fell outside the 'pool of ability', were assumed to be uneducable, now all students are expected to pursue strenuously their quota of examination grades to boost league tables, nationally and internationally. As the technology of 'school improvement' and leadership became pervasive, inclusion has become part of the discourse on performance and outcomes, (Slee, Weiner and Tomlinson 1998). Because of these various changes, there is no general theory of inclusive education which resembles an 'assembly hall within which gather disparate and desperate postulations and propositions about the intersection of human and social pathology with education' (Slee 2018: 11).

Slee's lament strikes a chord with the ransacking of the left and progressive lexicon by rightwing politicians. The secretary of state for education from 2010-2014, Michael Gove wellillustrated this point in his speeches, placing English academy schools within the lineage of the US Civil Rights Movement or quoting from Antonio Gramsci (for example, Gove 2013). The resulting dissonance is reminiscent of a much-quoted passage from William Morris' Dream of John Ball:

I pondered all these things, and how men (sic) fight and lose the battle, and the thing that they fought for comes about in spite of their defeat, and when it comes turns out not to be what they meant, and other men have to fight for what they meant under another name. (Morris 1888: 31)

A parallel process has taken place within co-operative circles. The co-operative movement originated as a democratic economic alternative to capitalism. It was a quiet yet powerful movement which reverberated widely. At one point the consumer co-operative movement 
enjoyed a membership of 10 million and a third of the British grocery trade. It redistributed significant sums of money and resources to working class communities. However, through much of the twentieth century, the co-op was squeezed by both the enlargement of state action as well as an ultra-competitive commercial sector which made use of co-operative innovations while twisting the language of co-operation into new shapes (Cole 1944; Wilson, Webster and Voberg-Rugh 2013). The decline of the co-operative movement coincided with the weakening of labour movement institutions and the political assault upon class politics. In the 1990s, left movements were forced to address neoliberalism and respond to the new world order. One tendency was in the direction of identity politics in which issues of race, gender, sexuality, and less commonly disability, were disaggregated, and many new insights and improvements followed on from these shifts. There were also attempts to bring these various strands back together, not least through the related notions of social justice and intersectionality (Commission on Social Justice 1994; Brah and Phoenix 1994).

Moreover, from the 1990s, 'new mutualism' aimed to re-co-operativise society by transforming public and private institutions through football supporters' clubs, care cooperatives, leisure trusts and other 'third sector' approaches (Birchall 2008; Woodin, Crook and Carpentier 2010). In 1995, the recodification of co-operative values and principles was a moment of international confidence in co-operation which questioned the ascendancy of new right free market approaches. Subsequently, in Britain, the Co-operative Commission of 2001 also asserted the need for 'successful co-operative businesses' to contribute to a new politics (Co-operative Commission 2001). Co-operative schools can be viewed as an example of these specific responses to seismic shifts in politics and the economy.

The related trajectories of co-operation and inclusion thus reveal scope for cross fertilisation. Ostensibly they occupy similar stables even though their respective horses may at times bolt in different directions. Philosophical notions of equality for all permeate both movements but can be applied in different ways. Each of them has a global presence but national traditions may vary considerably. In relation to schools, practical measures have also been advanced, 
such as Booth and Ainscow's Index for Inclusion which provided tools for whole school change as do co-op values which offer a mechanism for school transformation within a wider community (Booth and Ainscow 2002; Woodin 2015). To some extent, the language of each movement has been stolen and re-appropriated by others less sympathetic to the core vision. At each level, inequalities will be reproduced as well as challenged. The voluntary nature of co-operative schools means that they can choose to adopt co-operative structures for a variety of purposes and, in fact, some special schools have chosen to organise themselves into co-operative trusts, which is a useful mechanism for schools to collaborate but may provide a politically correct façade for the continuation of exclusionary practices (Slee 2018). Indeed, it has been argued that a values and social justice approach is fundamentally opposed to special education. Tony Booth spoke at a co-operative seminar where he was critical of those special schools to organise themselves into a co-operative cluster. Thus, inevitably the global and philosophical struggles have to be connected to specific dialogues and practical applications.

This special issue is dedicated to understanding the educational vision alongside the complexity, compromise and contradiction which is inherent in the co-operative project that attempts to thrive in a neoliberal context. It necessarily focuses upon values, democracy and leadership in co-operative schools. In doing so, it builds upon existing research on the emergence and development of co-operative schools (Thorpe 2011; Woodin 2012; Facer, Thorpe and Shaw 2012) as well as reflections on the role of values and the way they have been applied by teachers, pupils and external agencies in a range of settings (for instance, Glatter 2013; Woodin 2015; Davidge 2017; Dennis 2017; Ralls 2019). The movement has attracted people from diverse philosophical positions. This range of approaches to cooperative schools is reflected in the various articles included in this special issue.

John Schostak provides a theoretical lens on the importance of co-operative schools, highlighting their potential contribution to what he terms 'radical inclusion' within a 'society of equals' which nevertheless embraces difference. In marshalling philosophical thought from 
Baruch Spinoza to Pierre Rosanvallon, he outlines a vision in which freedom and equality are co-extensive, the kernel of which Schostak detects in co-operative schools. Martin Mills and lan Hextall provide an overview of the spread of the movement based upon a database of co-operative schools which was compiled in 2014 at a time when the movement had witnessed an explosive growth across England with almost 800 schools. They draw out several interesting correlations between the political, economic and social complexion of the areas in which schools were located and highlight strongholds such as the South West and North East of England. Many schools were located in rural Conservative-voting areas, not just the urban centres where such schools might be expected to be found. Their analysis of interviews confirms an overall interest in socially just schooling which has attracted staff to co-operative schools.

Three further papers analyse specific aspects of the co-operative system of schooling. Deborah Ralls assesses a co-operative secondary school's journey of 'becoming cooperative' as it engaged with pupils and parents. She examines the tensions which arose in the attempt to promote mutual and participative relationships. She distinguishes 'thick' collective forms of democracy as opposed to the thinner forms based upon the individual as consumer. Ralls argues that policy tends to be based upon the latter but would benefit from a better understanding of how equitable and collaborative relationships can develop. Sue Swaffield and Louis Major report on a detailed research project with a cluster of schools organised in a co-operative trust. Specifically, they examine the connections between leadership for learning and approaches based upon co-operative values. They identify a close match between the two, highlighting the shared discourses of leadership and learning. The co-operative trust enabled co-operation across schools as well as the sharing of leadership and expertise. Tom Woodin then evaluates the association between leadership and wider co-operative networks which vary in nature from many other educational networks. He analyses the difficulties in establishing a sustainable network and the resources required. Without more investment and, in the absence of time to consult and 
agree collective services, the network remained in its infancy. The current time is one in which other networks may emerge from informal connections and regional groupings.

Finally, two papers then consider the thorny relations between neoliberalism and cooperative schooling. Andrew Wilkins offers a critical analysis of co-operative schools, arguing against binary distinctions between neoliberalism and democratic schooling. Instead, he confuses this division with a 'processual' view of neoliberalism which highlights the 'messy actualities' and competing sets of interests in which co-operative schools are placed. The governance of such schools have to straddle neoliberal routines alongside their aspirations to democratic practice. Joanna Dennis analyses the relationship between cooperative schools and the neoliberal competitivism of the market place which has infused the academy schools' system of recent years. Through a 'contemporary history' of a cooperative academy she highlights the predicaments it faced, in relation to the notion of the 'self-improving school'. Dennis argues that co-operative schooling was not a completely new practice but fed on neoliberal approaches. Comprehending this level of complexity is characteristic of these articles as whole which, it is hoped, will open up new insights and approaches to co-operative schools and their relation to inclusion and an inclusive society.

\section{References}

Barton, Len. ed. 1988. The Politics of Special Educational Needs. Lewes: Falmer Press.

Barton, Len and Felicity Armstrong. eds. 2007. Policy, Experience and Change: Cross Cultural Reflections on Inclusive Education. Dordrecht: Springer Books.

Birchall, Johnston. 2008. "The Mutualisation of Public Services in Britain: A Critical Commentary." Journal of Co-operative Studies 41 (2): 5-16.

DfE (Department for Education). 2016. Co-operative Academy Trust Articles of Association: Model Six, May. London: DfE

Booth, Tony and Mel Ainscow. 2002. Index for Inclusion: Developing Learning and Participation in Schools. Bristol: Centre for Studies on Inclusive Education. 
Brah, Avtar and Ann Phoenix. 2004. "Ain't I A Woman? Revisiting Intersectionality". Journal of International Women's Studies, 5 (3): 75-86.

CEO 2016. Interviewed by Tom Woodin, 2016.

Chitty, Clyde. 2014. Education Policy in Britain. Basingstoke: Palgrave Macmillan.

Cole, G. D. H. 1944. A Century of Co-operation. Manchester: Co-operative Union.

Commission on Social Justice. 1994. Social Justice: Strategies for National Renewal. London: Vintage.

Co-operative Commission. 2001. The Co-operative Advantage: Creating a Successful Family of Co-operative Businesses. Co-operative Commission.

Co-operativesUK. 2018. The Co-operative Economy 2018. Manchester: Cooperatives UK. http://reports.uk.coop/economy2018/. Accessed 20 February 2019.

Davidge, Gail, Keri Facer and John Schostak. 2015. "Co-operatives, Democracy and Education: A Critical Reflection". In Co-operation, Learning and Co-operative Values, edited by Tom Woodin. London: Routledge.

Dennis, Joanna. 2018. "Imagining Powerful Co-operative Schools: Theorising Dynamic Co-operation with Spinoza". Educational Philosophy and Theory 50 (9): 849-857. DOI: 10.1080/00131857.2017.1382350

Facer, Keri, Julie Thorpe and Linda Shaw. 2012. "Co-operative Education and Schools: an old idea for new times?" Power and Education, 4 (3): 327-341.

Glatter, Ron. 2013. "To Whom Should our Schools Belong? Towards a New Model of Ownership". In Making it Mutual: the Ownership Revolution that Britain Needs, edited by Caroline Julian. London: ResPublica.

http://www.respublica.org.uk/item/Making-it-Mutual.

Gove, Michael. 2013. The civil rights struggle of our time: Secretary of State for Education Michael Gove's speech to the Mayor of London's education conference. https://www.gov.uk/government/speeches/the-civil-rights-struggle-of-our-time. Accessed 12 January 2017.

Gurney, Peter. 1996. Co-operative Culture and the Politics of Consumption in England 1870-1930. Manchester: Manchester University Press.

House of Commons Education Committee. 2013. School Partnerships and Cooperation. London: Stationery Office.

ICA (International Co-operative Alliance) (2019) Statement on Co-operative Identity, https://www.ica.coop/en/cooperatives/cooperative-identity. Accessed 2 February 2019). 
Morris, William. 1888. A Dream of John Ball. London: Reeves and Turner.

Ralls, Deborah. 2019 in press. "Reimagining Education Policy: Co-operative Schools and the Social Solidarity Alternative". In Learning for a Co-operative World:

Education, Social Change and the Co-operative College, edited by Tom Woodin and Linda Shaw. London: Trentham/UCL Press, 154-168.

Slee, Roger. 2018. Inclusive Education Isn't Dead, It Just Smells Funny. Abingdon: Routledge.

Slee, Roger, Gaby Weiner and Sally Tomlinson. 1998. School Effectiveness for Whom? Challenges to the School Effectiveness and School Improvement Movements. London: Falmer Press.

Thorpe, Julie. 2011. "Co-operative Schools in the UK." Journal of Co-operative Studies 44 (3): 57-62.

Todd, Nigel. 2013. "The Wallsend Owenites”, Forum 55 (2): 279-292.

http://doi.org/10.2304/forum.2013.55.2.279

Tyack, David and Larry Cuban. 1995. Tinkering Towards Utopia. A Century of Public School Reform. Cambridge, MA.: Harvard University Press.

UNESCO. 1994. The Salamanca Statement and Framework for Action on Special Needs Education. Paris: UNESCO.

Vernon, Keith. 2013. "Co-operative Education and the State, c.1895-1935", Forum 55 (2): 293-308. http://doi.org/10.2304/forum.2013.55.2.293.

Wilson, John F., Anthony Webster and Rachael Vorberg-Rugh. 2013. Building Cooperation: A Business History of the Co-operative Group, 1863-2013. Oxford: Oxford University Press.

Woodin, Tom. 2011. "Co-operative Education in the Nineteenth and Early Twentieth Centuries: Context, Identity and Learning." Chapter 5. In The Hidden Alternative: Cooperative Values, Past, Present and Future, edited by Anthony Webster, Linda Shaw, John K. Walton, Alyson Brown, and David Stewart. Manchester: Manchester University Press, 78-95.

Woodin, Tom. 2015. Co-operation, Learning and Co-operative Values. London: Routledge.

Woodin, Tom, David Crook and Vincent Carpentier. 2010. Community and Mutual Ownership - a Historical Review. York: Joseph Rowntree Foundation.

Woodin, Tom, Keith Vernon and Linda Shaw. 2019 forthcoming. The Co-operative College and a Century of Social Change. London: Palgrave Macmillan. 
Woodin, Tom and Michael Fielding. 2013. "Co-operative Education for a New Age?" Forum 55 (2) 179-184. 